\title{
ANALISIS SHIFT-SHARE TERHADAP PEREKONOMIAN KOTA SORONG.
}

\author{
Shift-Share Analysis on the Economic of Sorong City
}

\section{Hans Sammy Marthin Salakory ${ }^{1^{*}}$, Febby Sonya Matulessy ${ }^{2}$}

${ }^{1,2}$ Program Studi Perencanaan Wilayah Kota, Fakultas Teknik Sipil dan Perencanan, Institut Sains dan Teknologi Indonesia (ISTI) Manokwari Jl. Pasir Putih, Bakaro, Manokwari, 98311, Indonesia

e-mail:1* hans.salakory@gmail.com ; 2febbysonya@gmail.com Corresponding author*

\begin{abstract}
Abstrak
Pertumbuhan PDRB Kota Sorong dalam beberapa tahun terakhir terus mengalami perlambanan, perlambanan ini menunjukan kinerja perekonomian daerah yang kurang baik sebagai akibat pemanfaatan faktor produksi yang tidak optimal. Penelitian ini bertujuan untuk menghitung dan menganalisis pertumbuhan sektor-sektor ekonomi, daya saing perekonomian serta profil pertumbuhan sektor-sektor ekonomi di Kota Sorong dengan proksi PDRB tahun 2013 sampai dengan 2018. Metode analisis yang digunakan adalah metode deskriptif dengan pendekatan analisis Shift-Share. Hasil penelitian menunjukan bahwa pertumbuhan perekonomian Papua Barat telah memberikan dampak bagi sektor-sektor ekonomi di Kota Sorong, sektor yang mendapat dampak terbesar adalah sektor Konstruksi dan yang terkecil adalah sektor Pengadaan Listrik dan Gas. Sektor-sektor ekonomi dengan pertumbuhan yang lamban sebagai akibat pertumbuhan sektor yang sama pada tingkat Provinsi adalah sektor Pertanian, Kehutanan dan Perikanan, sektor Pertambangan dan Penggalian, serta sektor Industri Pengolahan. Dari sisi daya saing hanya sektor Pertambangan dan Penggalian di Kota Sorong yang memilki daya saing terhadap sektor yang sama di Papua Barat. Sektor-sektor ekonomi dengan pertumbuhan yang progresif hanya enam sektor dan sebanyak sebelas sektor ekonomi yang memiliki pertumbuhan yang lamban.
\end{abstract}

Kata Kunci: Analisis Shift-Sahre, Pertumbuhan Nasional, Pertumbuhan Proporsional, Pertumbuhan Pangsa Wilayah, Pergeseran Bersih

\begin{abstract}
The growth of GDRP of Manokwari regency has a negative growth in the last few years, this shows the poor performance of the regional economy as a result of the utilization of production factors that are not optimal. This research aims to calculate and analyze the growth of economic sectors, the competitiveness of the economy and the growth profile of economic sectors in Sorong city with a proxy for GDRP from 2013 to 2018. The analysis method used is quantitative desctitive method with Shift-Share analysis approach. The research results show that positive growth in the economy of West Papua has had a positive impact on economic sectors in Sorong city. The sector that has the biggest impact from the economic growth of West Papua province is the construction sector and the smallest is the electricity and gas sector. At the provincial level, the sectors with negative growth are Agriculture, Forestry and Fishing sectors, Mining and Quarrying sectors, as well as the manufacturing sector which causes sluggish growth in the same sectors in the city of Sorong. In terms of competitiveness, only the Mining and Quarrying sector in the city of Sorong has competitiveness against the same sector in West Papua province. Only six economic sectors with progressive growth and as many as eleven economic sectors have negative growth.
\end{abstract}

Keywords: Shift-Share analysis, National Share, Proportional Shift and Differential Shift, Net Shift 


\section{PENDAHULUAN}

Pembangunan ekonomi adalah pembangunan kemakmuran ekonomi negara atau daerah guna kesejahteraan penduduknya. Pembangunan ekonomi merujuk pada upaya meningkatkan standar hidup penduduk suatu negara/bangsa terkait dengan pertumbuhan yang berkelanjutan dari ekonomi yang sederhana, berpendapatan rendah menuju ekonomi moderen, yang berpendapatan tinggi. Pembangunan ekonomi mencakup proses dan kebijakan yang diterapkan negara untuk memperbaiki ekonomi, politik, dan kesejahteraan sosial warga negara/penduduknya [1]. Salah satu indikator tingkat kesejahteraan masyarakat dilihat dari aspek ekonominya, dapat diukur dengan pendapatan nasional perkapita, dengan semakin tingginya pendapatan perkapita semakin tinggi pula kesejahteraan dan merupakan kemajuan dalam pembangunan ekonomi.[2]

Keberhasilan pembangunan ekonomi tergambar pada pertumbuhan ekonomi. Pertumbuhan ekonomi dapat dinilai sebagai dampak kebijaksanaan pemerintah, khususnya dalam bidang ekonomi. Pertumbuhan ekonomi merupakan laju pertumbuhan yang dibentuk dari berbagai macam sektor ekonomi yang secara tidak langsung menggambarkan tingkat pertumbuhan yang terjadi dan sebagai indikator penting bagi daerah untuk mengevaluasi keberhasilan pembangunan.[3]

Faktor utama penentu pertumbuhan ekonomi suatu daerah adalah adanya permintaan terhadap barang dan jasa sehingga sumber daya lokal berpotensi menghasilkan pendapatan daerah sekaligus dapat menciptakan peluang kerja di daerah. Pertumbuhan ekonomi menunjukan peningkatan dalam produksi barang maupun jasa dalam suatu perekonomian, sehingga pertumbuhan ekonomi ini merupakan salah satu indikator penting di dalam melakukan suatu analisis pembangunan ekonomi.[4]

Keberhasilan pembangunan ekonomi daerah mempertinggi penggunaan semua potensi yang ada baik sumber daya alam maupun sumber daya manusia. Keberhasilan pembangunan ekonomi berdampak kepada peningkatan tingkat kesejahteraan masyarakat. Potensi daerah berbeda satu dengan lainnya, oleh kerena itu maka potensi sumber daya yang ada harus digali dan dimanfaatkan secara efisien dan efektif untuk mendukung kegiatan pertumbuhan ekonomi daerah agar pembangunan daerah yang cita-citakan bisa terealisasikan [5]. Agar pembangunan daerah lebih terfokus, salah satu upaya yang dapat dilakukan adalah mendeteksi sektor unggulan dan daya saing daerah tersebut. [6]

Salah satu cara untuk menilai potensi dan daya saing perekonomian daerah adalah analisis ShiftShare. Analisis Shift-Share merupakan suatu analisis yang dilakukan untuk mengetahui perubahan dan pergeseran sektor atau industri pada perekonomian regional maupun lokal. Analisis Shift-Share menggambarkan kinerja sektorsektor di suatu wilayah [7]. Hal yang sama juga diungkapkan oleh [8] bahwa, analisis shift share adalah salah satu analisis yang sederhana dengan menggunakan konsep proporsi dan pertumbuhan dimana kita dapat melihat sektor-sektor apa saja di suatu daerah yang lebih unggul dibandingkan daerah yang lain. Dengan menggunakan perhitungan Shift-Share akan memungkinkan dihasilkannya perhitungan antar waktu (pertumbuhan) yang melibatkan daerah/negara lain (dengan penghitungan yang sederhana).

Penelitian [6] menunjukan bahwa, pertumbuhan ekonomi Provinsi Daerah Istimewa Yogyakarta berpengaruh sebesar 95 persen terhadap perekonomian yang ada di Kabupaten Sleman. Sedangkan untuk pergeseran diferensial atau Differential Shift terdapat 4 persen pertumbuhan yang identik di Kabupaten Sleman sebagai muatan lokal perekonomian. Penelitian lain yang dilakukan oleh [9] menunjukan bahwa sektor Pengadaan Listrik dan Gas, sektor Konstruksi, sektor Penyediaan Akomodasi dan Makan Minum, sektor Jasa Keuangan dan Asuransi, sektor Jasa Kesehatan dan Kegiatan Sosial sangat berpotensi untuk dikembangkan dan dijadikan sumber daya untuk dimanfaatkan dalam membangun Kabupaten Minahasa Selatan karna memiliki keunggulan yang komparatif dan menjadi sumber pertumbuhan ekonomi. Begitupula dengan penelitian di Kabupaten Kepulauan Meranti [10], ditemukan bahwa dengan analisis Shift-Share terdapat 3 sektor ekonomi yang pertumbuhannya progresif (maju), yaitu sektor Pertambangan \& Penggalian; sektor Transportasi dan Pergudangan; dan sektor Jasa Perusahaan. Penelitian yang dilakukan [7] terhadap perekonomian kabupaten Aceh Besar menunjukan bahwa, sebagian sektor ekonomi Kabupaten Aceh Besar termasuk sektor unggulan yang tumbuh cepat pada perekonomian di Provinsi Aceh. Hanya sektor pengadaan listrik dan gas yang tidak unggul di Aceh Besar.

Kota Sorong sebagai salah satu daerah otonom terus mengalami perkembangan pembangunan yang sangat pesat, berbagai upaya telah dilakukan pemerintah Kota Sorong dengan tujuan mengerakan sektorsektor ekonomi serta meningkatkan perekonomian daerahnya, upaya yang dilakukan adalah melalui regulasiregulasi ataupun pembangunan telah dilakukan, seperti halnya renovasi pasar tradisional, relokasi pedagang kaki lima, juga adanya pasar harian, pasar pojok, sampai pada event-event yang di selenggarakan pemerintah 
Kota untuk menarik wisatawan dan menambah produktivitas masyarakat.[11]. Semua upaya yang telah dilakukan tentunya dengan tujuan untuk menggerakan sektor-sektor ekonomi serta memacu pertumbuhan ekonomi Kota Sorong.

Semua aktifitas perekonomian daerah terdata secara komulatif dalam Produk Domestik Regional Bruto (PDRB). Kontribusi sektor-sektor ekonomi terhadap PDRB total berbeda satu dengan lainnya, sektor dengan rerata kontribusi terbesar adalah jasa kontruksi yakni 25,14 persen, selanjutnya sektor pedagang besar, pengolahan sampah, reparasi mobil dan sepeda motor sebesar 17,82 persen, diikuti oleh sektor administrasi pemerintahan, pertahanan dan jaminan sosial sebesar 9,95 persen, sementara sektor dengan kontribusi terendah adalah sektor pengadaan listrik dan gas yakni sebesar 0,10 persen. Fenomena lain yang nampak adalah sektor pertaninan yang selama ini memegang peranan penting dalam perekonomian nasional maupun regional justru pada perekonomian Kota Sorong menunjukan kontribusi yang semakin menurun dengan rerata kontribusi hanya sebsar 8,07 persen. Pertumbuhan PDRB Kota Sorong [12] menunjukan trend perlambanan selama tahun 2013 hingga 2018. Pada tahun 2013 pertumbuhan PDRB sebesar 11,83 persen dan meningkat pada tahun 2014 menjadi 12,10 persen. Selanjutnya PDRB Kota Sorong mengalami perlambanan hingga tahun 2018 sebesar 6,73 persen. Semakin melambannya pertumbuhan PDRB Kota Sorong secara makro akan berdampak pada daya saing wilayah tersebut. Optimalisasi pemanfaatan sumber daya lokal serta pemanfaat peluang yang tidak maksimal meyebabkan ketidakstabilan pertumbuhan PDRB. Glasson [13] mengatakan pertumbuhan regional dapat terjadi sebagai akibat dari faktor penentu endogen ataupun eksogen, endogen yaitu faktor-faktor yang terdapat di dalam daerah yang bersangkutan. Eksogen adalah faktor-faktor di luar daerah, atau kombinasi dari keduanya. Penentu endogen, meliputi distribusi faktor-faktor produksi seperti tanah, tenaga kerja, dan modal sedangkan penentu eksogen adalah tingkat permintaan dari daerah lain terhadap komoditi yang dihasilkan oleh daerah tersebut.

Untuk mencapai suatu tingkat pertumbuhan ekonomi yang stabil dan ideal maka perencanaan pengembangan daerah harus diarahkan untuk pengembangan aktifitas ekonomi unggulan serta memiliki daya saing. Sektor ekonomi unggul dan punya daya saing adalah; sektor yang memiliki laju tumbuh yang tinggi; memiliki angka penyerapan tenaga kerja yang relatif besar; memiliki keterkaitan antar sektor yang tinggi baik kedapan maupun kebelakang; mampu menciptakan nilai tambah yang tinggi [14]. Berkaitan upaya penentuan daya saing sektor ekonomi Kota Sorong dan dihubungkan dengan beberapa penelitian sebelumnya maka salah satu model statistik yang dapat digunakan adalah analisis Shift-Share. Dari analisis ini ada tiga hal yang diperoleh, yaitu; pertumbuhan sektor-sektor ekonomi dibandingkan dengan sektor yang sama di daerah atas, pergeseran bersih yang mengukur perubahan relatif, perubahan atau penurunan pada daerah dibandingkan dengan perekonomian yang lebih besar yang dijadikan acuan serta membantu kita dalam menentuka seberapa jauh daya saing industri daerah (lokal) dengan perekonomian yang di jadikan acuan [15], [16].

Berdasarkan paparan latar belakang maka permasalahannya adalah Bagaimana pertumbuhan sektorsektor ekonomi Kota Sorong dibandingkan dengan sektor yang sama di Provinsi Papua Barat? Sektor apa saja yang memilki daya saing terhadap perekonomian Provinsi Papua Barat serta bagaimana profil pertumbuhan ekonomi sektor-sektor tersebut? Sesuai dengan permasalahan tersebut maka tujuan penulisan ini adalah: Menghitung dan menganalisis pertumbuhan sektor-sektor ekonomi Kota Sorong dibandingkan dengan sektor yang sama di Provinsi Papua Barat, menghitung dan menganalisis daya saing perekonomian Kota Sorong terhadap perekonomian Papua Barat serta menetukan profil pertumbuhan sektor-sektor ekonomi tersebut.

\section{METODE PENELITIAN}

\section{a. Ruang Lingkup Penelitian}

Penelitian ini dilakukan terhadap perekonomian Kota Sorong dengan tujuan menghitung dan menganalisis pertumbuhan dan pergeseran, daya saing, dan profil perekonomiannya. Objek penelitian adalah aktivitas perekonomian yang tercatat secara sistematis dalam bentuk PDRB Kota Sorong dan Provinsi Papua Barat tahun 2013 s.d. 2018 sebagai data sekunder yang diperoleh lewat studi dokumen.

\section{b. Metode Analisis Data}

Metode analisis yang digunakan adalah metode deskriptif dan untuk menjawab pertanyaan penelitian digunakanlah teknik analisis Shift-Share. Analisis Shift-Share berguna untuk menganalisis perubahan berbagai indikator kegiatan ekonomi, seperti produksi dan kesempatan kerja, pada dua titik waktu. Dalam analisis ini diasumsikan bahwa, perubahan tenaga kerja/produksi pada suatu wilayah antara tahun dasar 
dengan tahun akhir analisis dibagi menjadi tiga komponen pertumbuhan, yaitu: komponen pertumbuhan nasional (national growth component) disingkat $\mathrm{N}$, komponen pertumbuhan proporsional (proportional or industrial mix growth component) disingkat PP dan komponen pertumbuhan pangsa wilayah (regional snare growth component) disingkat PPW.

Langkah-langkah analisis Shift-Share [17] adalah:

1. Menentukan indikator kegiatan ekonomi (produksi/kesempatan kerja) digunakan untuk melihat perbandingan produksi/kesempatan kerja sektor ekonomi wilayah tertentu. Rasio ini terdiri dari $\mathrm{r} i, \mathrm{R} i, \mathrm{Ra}$.

a. $r_{i}=\frac{Y_{i j}^{I}-Y_{i j}}{Y_{i j}}$

b. $R_{i}=\frac{Y_{i .}^{i}-Y_{i}}{Y_{i .}}$

c. $R_{a}=\frac{Y_{. .}^{i}-Y_{. .}}{Y_{. .}}$

Dimana:

$\mathrm{r} i=\quad$ rasio sektor $i$ di Kota Sorong

$\mathrm{R} i=$ rasio sektor $i$ di Papua Barat

$\mathrm{Ra} \quad=\quad$ rasio toatl di Papua Barat

Y $i j=\quad$ pendapatan tahun dasar sektor $i$ Kota Sorong

Y $i . \quad=\quad$ pendapatan tahun dasar sektor $i$ Papua Barat

Y.. $\quad=\quad$ pendapatan total Papua Barat

2. Menghirtung Komponen pertumbuhan wilayah terdiri dari komponen pertumbuhan nasional (PN), pertumbuhan proporsional (PP), dan pertumbuhan pangsa wilayah (PPW):
a. $P N_{i j}=\left(R_{a}\right) Y_{i j}$
b. $P P_{i j}=\left(R_{i}-R_{a}\right) Y_{i j}$

Dengan ketentuan jika:

PPij < 0 maka sektor di Kota Sorong pertumbuhannya lamban

PPij $>0$ maka sektor di Kota Sorong pertumbuhannya cepat

c. $P P W_{i j}=\left(r_{i}-R_{i}\right) Y_{i j}$

Dengan ketentuan jika:

PPWij < 0 sektor $i$ di Kota Sorong mempunyai daya saing yang baik dibanding dengan sektor yang sama diwilayah yang menjadi perbandingan

PPWij $<0$ sektor $i$ di Kota Sorong tidak mempunyai daya saing yang baik dibanding dengan sektor yang sama di wilayah yang menjadi perbandingan.

3. Menentukan pergeseran bersih

Bila komponen PP dan PPW dijumlahkan maka akan diperoleh pergeseran bersih yang dapat digunakan untuk mengidentifikasi pertumbuhan suatu sektor perekonomin. Pergeseran sektor i diwilayah $\mathrm{j}$ dihitung dengan rumus berikut:

$$
P B_{i j}=P P_{i j}+P P W_{i j}
$$

Dengan ketentuan jika:

$\mathrm{PB} i j \quad>0 \quad$ pertumbuhan sektor $i$ di Kota Sorong termasuk dalam komponen progresif (maju)

$\mathrm{PB} i j<0 \quad$ pertumbuhan sektor i di Kota Sorong termasuk dalam komponen lamban.

4. Menentukan presentase ketiga pertumbuhan wilayah dapat dirumuskan:

a. $\% P N_{i j}=R_{a}$ atau $\% P N_{i j}=\left(P N_{i j}\right) / Y_{i j} x 100 \%$

b. $\% P P_{i j}=R_{i}-R_{a}$ atau $\% P P_{i j}=\left(P P_{i j}\right) / Y_{i j} x 100 \%$

c. $\% P P W_{i j}=r_{i}-R_{i}$ atau $\% P P W_{i j}=\left(P P W_{i j}\right) / Y_{i j} x 100 \%$

5. Aplikasi Analisis Shift-Share

Untuk mengevaluasi profil pertumbuhan sektor-sektor perekonomian pat dilakukan dengan menggunakan bantuan 4 kuadran yang terdapat pada garis angan. Sumbu horizontal menggambarkan persentase perubahan komponen pertumbuhan proporsional $\left(\mathrm{PP}_{i j}\right)$, sedangkan sumbu vertikal merupakan persentase pertumbuhan pangsa wilayah $\left(\mathrm{PPW}_{i j}\right)$. Dengan demikian pada sumbu horizontal dapat $\mathrm{PP}$ sebagai absis, sedangkan PPW sebagai ordinat.

Penjelasan masing-masing kuadran yang terdapat pada Gambar 4 adalah sebagai berikut:

a. Kuadran I merupakan kuadran dimana PP dan PPW sama-sama bernilai positif. Hal ini menunjukkan 
bahwa sektor-sektor di wilayah yang bersangkutan memiliki pertumbuhan yang cepat (dilihat dari nilai PP-nya) dan memiliki daya saing yang lebih baik apabila dibandingkan dengan wilayah- wilayah lainnya (dilihat dari nilai PPW-nya).

b. Kuadran II menunjukkan bahwa sektor-sektor ekonomi di wilayah yang bersangkutan pertumbuhannya cepat (PP-nya bernilai positif), tetapi daya saing wilayah untuk sektor-sektor tersebut dibandingkan dengan wilayah lainnya kurang baik (PPW-nya bernilai negatif).

c. Kuadran III merupakan kuadran dimana PP dan PPW-nya bernilai negatif. Hal ini menunjukkan bahwa sektor-sektor ekonomi di wilayah yang bersangkutan memiliki pertumbuhan yang lambat dengan daya saing yang kurang baik jika dibandingkan dengan wilayah lain.

d. Kuadran IV menunjukkan bahwa sektor-sektor ekonomi pada wilayah yeng bersangkutan memiliki pertumbuhan lambat (dilihat dari nilai PP-nya yang negatif), tetapi daya saing wilayah untuk sektor-sektor tersebut baik jika dibandingkan dengan wilayah lainnya (dilihat dari nilai PPW-nya yang positif).

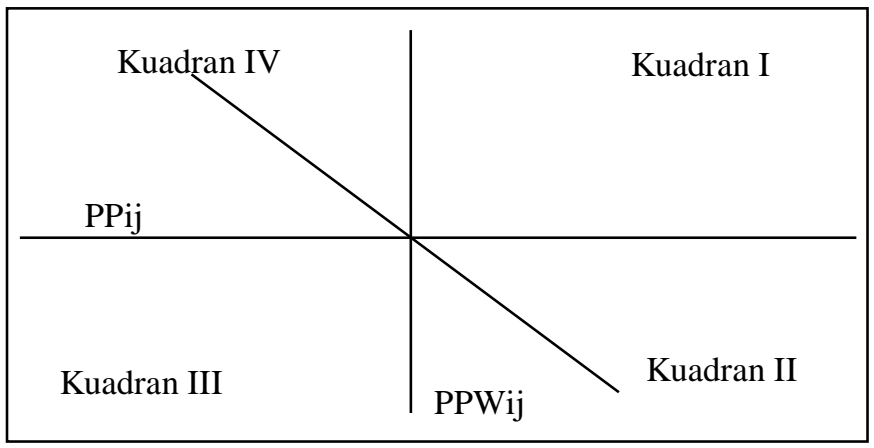

Gambar 1. Profil Pertumbuhan Sektor Perekonomian

Pada Gambar 4 terdapat garis yang memotong Kuadran II dan IV yang membentuk sudut $45^{\circ}$. Garis tersebut merupakan garis yang menunjukkan pergeseran bersih bernilai nol $\left(\mathrm{PB}_{j}=0\right)$. Bagian atas garis tersebut nunjukkan $\mathrm{PB}_{j}>0$ yang mengindikasikan bahwa sektor-sektor tersebut rtumbuhannya progresif (maju). Sebaliknya, di bawah garis $45^{\circ}$ berarti $\mathrm{PB}_{j}<0$ nunjukkan sektor-sektor yang lamban.

\section{HASIL DAN PEMBAHASAN}

\section{a. Kondisi Perekonomian}

Titik berat pembangunan ekonomi di daerah harus diarahkan pada dikeluarkannya kebijakankebijakan pembangunan yang didasarkan pada kekhasan daerah yang bersangkutan (endogenous development) dengan menggunakan potensi sumber daya manusia, kelembagaan, dan sumber daya fisik secara lokal (daerah). Orientasi ini mengarahkan kita kepada pengambilan inisiatif-inisiatif yang berasal dari daerah tersebut dalam proses pembangunan untuk menciptakan kesempatan kerja baru dan merangsang peningkatan kegiatan ekonomi[18].

Tujuan utama pembangunan ekonomi daerah adalah untuk meningkatkan jumlah dan jenis peluang kerja untuk masyarakat daerah. Oleh karena itu, maka pemerintah daerah beserta masyarakatnya harus secara bersama-sama mengambil inisiatif pembangunan daerah. Penggunaan sumber daya lokal yang ada harus direncanakan dan digunakan seefisien untuk membangun perekonomian daerah.

Berdasarkan data PDRB Kota Sorong dan Provinsi Papua Barat selama periode tahun 2013 s.d. 2018 [12], [19], [20] dihitunglah pertumbuhan PDRB harga konstan berdasarkan Lapangan Usaha sebagai berikut: 


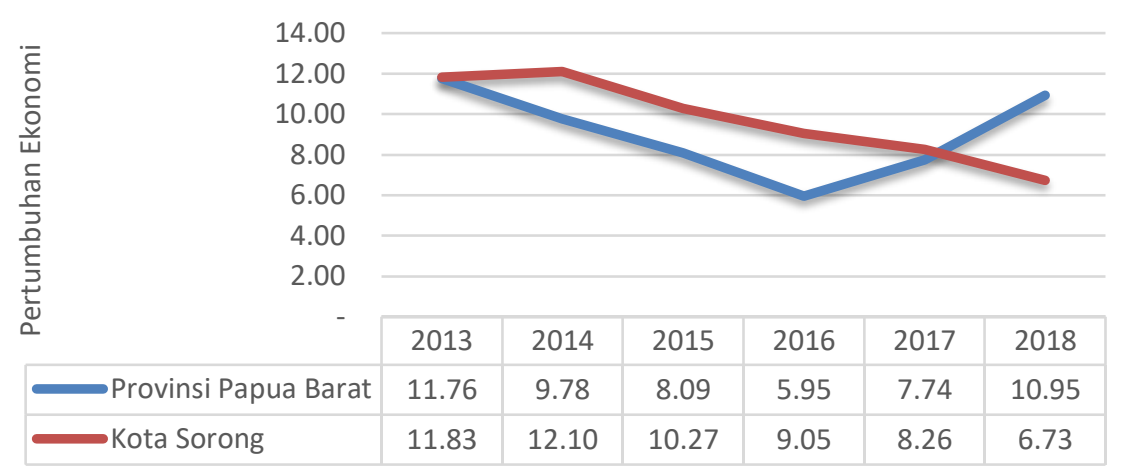

Gambar 2. Pertumbuhan PDRB Provinsi Papua Barat dan Kota Sorong Tahun 2013-2018 Sumber: BPS Provinsi Papua Barat dan Kota Sorong, 2019

Mencermati Gambar 2, pertumbuhan ekonomi Kota Sorong mengalami perlambanan selama periode tahun 2014 sampai 2018, perlambanan pertumbuhan ekonomi Kota sorong adalah merupakan gambaran dari menurunnya produksi disetiap lapangan usaha tanpa dipengaruhi inflasi. Gambar 2 juga menunjukan perekonomian Provinsi Papua Barat yang walaupun sempat mengalami perlambanan, tetapi kemudian mengalami percepatan pertumbuhan pada tahun 2017 dan 2018, bahkan pertumbuhan ekonomi di tahun 2018 mencapai titik tertinggi selama tahun pengamatan yakni 10,95 persen. Dengan capaian ini, menunjukan kemajuan diberbagai bidang pembangunan seperti terkoneksi hampir seluruh kabupaten dan Kota, baik melalui laut, udara, telah berkontribusi dalam proses pembentukan dan pembangunan sebagai fasilitas keamanan.

Walaupun ekonomi Papua Barat mengalami peningkatan, namun masih banyak tugas utama yang perlu diselesaikan seperti peningkatan akses dan kualitas pelayanan kesehatan, pelayanan pendidikan untuk meningkatkan sumber daya manusia Papua di Papua Barat demi menjamin kesejahteraan dan kemakmuran masyarakat serta kemajuan di Papua Barat.

\section{b. Analisis Pergeseran struktur Ekonomi Kota Sorong}

Analisis pergeseran struktur ekonomi bertujuan untuk menganalisis pertumbuhan dan daya saing perekonomian suatu wilayah dan proses analisis bisa dilakukan dengan pendekatan Shift-Share. Dasar perhitungan Shift-Share adalah PDRB harga konstan tahun 2010 berdasarkan lapangan usaha pada dua titik waktu. Berikut data PDRB harga konstan tahun 2010 berdasarkan lapangan usaha tahun 2013 dan 2018:

Tabel 1. PDRB Kota Sorong dan Provinsi Papua Barat Tahun 2013 dan 2018

\begin{tabular}{llrrrr}
\hline \multirow{2}{*}{ No } & \multirow{2}{*}{ Lapangan Usaha/ Idustry } & \multicolumn{2}{c}{ Kota Sorong } & \multicolumn{2}{c}{ Papua Barat } \\
\cline { 3 - 6 } & & $\mathbf{2 0 1 3}$ & $\mathbf{2 0 1 8}$ & $\mathbf{2 0 1 3}$ & \multicolumn{1}{c}{$\mathbf{2 0 1 8}$} \\
\hline 1 & Pertanian, Kehutanan, dan Perikanan & $571,414.54$ & $758,335.32$ & $5,557,691.48$ & $8,329,310.07$ \\
\hline 2 & Pertambangan dan Penggalian & $108,287.55$ & $131,332.31$ & $12,262,098.55$ & $14,319,751.06$ \\
\hline 3 & Industri Pengolahan & $469,888.27$ & $557,395.48$ & $16,049,531.20$ & $21,359,149.10$ \\
\hline 4 & Pengadaan Listrik dan Gas & $7,846.46$ & $8,764.72$ & $14,422.58$ & $35,287.01$ \\
\hline 5 & Pengadaan Air, Pengelolaan Sampah & $24,199.13$ & $30,271.28$ & $53,917.17$ & $81,133.60$ \\
\hline 6 & Konstruksi & $1,453,202.24$ & $2,734,715.57$ & $6,282,087.56$ & $12,254,875.44$ \\
\hline 7 & Perdagangan Besar dan Eceran & $1,197,647.80$ & $1,827,997.64$ & $2,879,672.24$ & $5,584,727.64$ \\
\hline 8 & Transportasi dan Pergudangan & $447,412.36$ & $721,262.93$ & $1,171,890.25$ & $2,376,702.95$ \\
\hline 9 & Penyediaan Akomodasi Makan Minum & $99,103.28$ & $137,112.19$ & $286,923.51$ & $513,003.62$ \\
\hline 10 & Informasi dan Komunikasi & $390,379.57$ & $637,576.89$ & $744,458.10$ & $1,299,167.19$ \\
\hline 11 & Jasa Keuangan dan Asuransi & $292,063.79$ & $387,234.66$ & $761,132.46$ & $1,204,808.90$ \\
\hline 12 & Real Estat & $187,116.48$ & $294,874.84$ & $550,588.60$ & $1,024,199.91$ \\
\hline 13 & Jasa Perusahaan & $23,894.15$ & $31,602.13$ & $54,067.26$ & $91,860.25$ \\
\hline 14 & Administrasi Pemerintahan, Pertahanan & $636,848.33$ & $1,012,907.41$ & $4,633,717.52$ & $8,448,092.00$ \\
\hline 15 & Jasa Pendidikan & $415,606.22$ & $620,013.37$ & $1,170,071.55$ & $1,859,030.69$ \\
\hline 16 & Jasa Kesehatan dan Kegiatan Sosial & $139,710.21$ & $186,628.46$ & $384,482.88$ & $628,279.31$ \\
\hline 17 & Jasa lainnya & $63,110.46$ & $89,651.37$ & $140,906.36$ & $233,543.45$ \\
\hline & Total & $6,527,730.84$ & $10,167,676.57$ & $52,997,659.27$ & $79,642,922.19$ \\
\hline
\end{tabular}

Sumber: BPS Provinsi Papua Barat dan Kota Sorong, 2019 


\section{i. Rasio PDRB Kota Sorong dan Provinsi Papua Barat Tahun 2013-2018}

Angka-angka pada PDRB tidak akan memberikan informasi yang sesungguhnya mengenai kondisi aktivitas pelaku ekonomi bila tidak dikembangkan dan dianalisis lebih mendalam. Berkaitan dengan analisis Shift-Share yang secara umum bertujuan melihat pergeseran struktur ekonomi di suatu wilayah maka proses analisis diawali dengan mencari ri (rasio pertambahan kegiatan sektor $i$ di Kota Sorong), Ri (rasio atau perubahan aktifitas ekonomi sektor $i$ di Provinsi Papua Barat), dan Ra (Perubahan total aktifitas perekonomian/PDRB Provinsi Papua Barat). Berikut perhitungan rasio ri, Ri, dan Ra pada Tabel 2 berikut:

Tabel 2. Rasio PDRB Kota Sorong dan Provinsi Papua Barat (Ra, Ri, ri)

\begin{tabular}{clccccc}
\hline No & \multicolumn{1}{c}{ Lapangan Usaha } & Ra & $\mathbf{R i}$ & ri & Ri-Ra & ri-Ri \\
\hline 1 & Pertanian, Kehutanan, dan Perikanan & 0,503 & 0,499 & 0,327 & $-0,004$ & $-0,172$ \\
\hline 2 & Pertambangan dan Penggalian & 0,503 & 0,168 & 0,213 & $-0,335$ & 0,045 \\
\hline 3 & Industri Pengolahan/Manufacturing & 0,503 & 0,331 & 0,186 & $-0,172$ & $-0,145$ \\
\hline 4 & Pengadaan Listrik dan Gas & 0,503 & 1,447 & 0,117 & 0,944 & $-1,330$ \\
\hline 5 & Pengadaan Air, Pengelolaan Sampah & 0,503 & 0,505 & 0,251 & 0,002 & $-0,254$ \\
\hline 6 & Konstruksi & 0,503 & 0,951 & 0,882 & 0,448 & $-0,069$ \\
\hline 7 & Perdagangan Besar dan Eceran; & 0,503 & 0,939 & 0,526 & 0,437 & $-0,413$ \\
\hline 8 & Transportasi dan Pergudangan & 0,503 & 1,028 & 0,612 & 0,525 & $-0,416$ \\
\hline 9 & Penyediaan Akomodasi Makan Minum & 0,503 & 0,788 & 0,384 & 0,285 & $-0,404$ \\
\hline 10 & Informasi dan Komunikasi & 0,503 & 0,745 & 0,633 & 0,242 & $-0,112$ \\
\hline 11 & Jasa Keuangan dan Asuransi & 0,503 & 0,583 & 0,326 & 0,080 & $-0,257$ \\
\hline 12 & Real Estat & 0,503 & 0,860 & 0,576 & 0,357 & $-0,284$ \\
\hline 13 & Jasa Perusahaan & 0,503 & 0,699 & 0,323 & 0,196 & $-0,376$ \\
\hline 14 & Administrasi Pemerintahan, Pertahanan & 0,503 & 0,823 & 0,591 & 0,320 & $-0,233$ \\
\hline 15 & Jasa Pendidikan & 0,503 & 0,589 & 0,492 & 0,086 & $-0,097$ \\
\hline 16 & Jasa Kesehatan dan Kegiatan Sosial & 0,503 & 0,634 & 0,336 & 0,131 & $-0,298$ \\
\hline 17 & Jasa lainnya & 0,503 & 0,657 & 0,421 & 0,155 & $-0,237$ \\
\hline
\end{tabular}

Sumber: Hasil perhitungan dan analisis, 2019

Tabel 2 menunjukan nilai Ra atau perubahan aktifitas ekonomi di Provinsi Papua Barat secara keseluruhan dari tahun 2013 ke 2018. Hasil perhitungan menunjukan, bahwa telah terjadi perubahan sebesar 0,503 atau 50,3 persen yang berarti perekonomian Provinsi papua Barat telah mengalami peningkatan sebesar 50,3 persen di tahun 2018 dibandingkan tahun 2013.

Selanjutnya nilai Ri yang adalah selisih antara PDRB Provinsi Papua Barat sektor $i$ pada tahun akhir (2018) dengan PDRB Provinsi Papua Barat sektor $i$ pada tahun dasar (2013). Berdasarkan hasil perhitungan seperti pada tabel di atas semua nilai Ri bernilai positif yang berarti semua sektor ekonomi di Provinsi Papua Barat mengalami perkembangan yang positif.

Komponen berikut adalah rasio ri yang adalah rasio perubahan aktivitas perekonomian sektor i di Kota Sorong, seperti rasio Ri demikian juga nilai ri semuanya bertanda positif, yang berarti selama tahun 2013 hingga 2018 sektor-sektor ekonomi mengalami perkembangan yang baik dan positif.

\section{ii. Analisis Komponen Pertumbuhan Wilayah Kota Sorong Tahun 2013-2018.}

Perekonomian daerah sangat didukung oleh sektor-sektor ekonomi di daerah tersebut, pertumbuhan dari sektor-sektor ekonomi tersebut sangat dipengaruhi oleh komponen pertumbuhan ekonomi baik secara sektoral maupun total dari daerah diatasnya. Dalam analisis Shift-Share komponen-komponen yang dimaksudkan adalah Pertumbuhan Nasional (PN), Pertumbuhan Proporsional (PP) dan Pertumbuhan Pangsa Wilayah (PPW). Komponen pertumbuhan PN, PP, dan PPW serta PB (Pergeseran Bersih) Kota Sorong dapat dilihat pada Tabel 3 berikut:

Tabel 3. Kompomen Pertumbuhan Nasional (PN) dan Pertumbuhan Proporsioanl (PP)

\begin{tabular}{llrrrr}
\hline \multirow{2}{*}{ No } & Lapangan Usaha/ Idustry & \multicolumn{2}{c}{ PNij } & \multicolumn{2}{c}{ PPij } \\
\cline { 3 - 6 } & & \multicolumn{1}{c}{ Miliar } & \% & Miliar & \% \\
\hline 1 & Pertanian, Kehutanan, dan Perikanan & $287,286.10$ & 50.28 & $(2,321.89)$ & $(0.41)$ \\
\hline 2 & Pertambangan dan Penggalian & $54,442.98$ & 50.28 & $(36,271.69)$ & $(33.50)$ \\
\hline 3 & Industri Pengolahan & $236,242.44$ & 50.28 & $(80,790.73)$ & $(17.19)$ \\
\hline
\end{tabular}




\begin{tabular}{|c|c|c|c|c|c|}
\hline 4 & Pengadaan Listrik dan Gas & $3,944.91$ & 50.28 & $7,406.17$ & 94.39 \\
\hline \multirow[t]{2}{*}{ No } & Lapangan Usaha/ Idustry & \multicolumn{2}{|l|}{ PNij } & \multicolumn{2}{|l|}{ PPij } \\
\hline & & Miliar & $\%$ & Miliar & $\%$ \\
\hline 5 & Pengadaan Air, Pengelolaan Sampah & $12,166.43$ & 50.28 & 48.86 & 0.20 \\
\hline 6 & Konstruksi & $12,166.43$ & 50.28 & $651,037.24$ & 44.80 \\
\hline 7 & Perdagangan Besar dan Eceran & $602,133.02$ & 50.28 & $522,892.12$ & 43.66 \\
\hline 8 & Transportasi dan Pergudangan & $224,942.39$ & 50.28 & $235,039.33$ & 52.53 \\
\hline 9 & Penyediaan Akomodasi Makan Minum & $49,825.46$ & 50.28 & $28,262.53$ & 28.52 \\
\hline 10 & Informasi dan Komunikasi & $196,268.41$ & 50.28 & $94,610.41$ & 24.24 \\
\hline 11 & Jasa Keuangan dan Asuransi & $146,838.87$ & 50.28 & $23,409.84$ & 8.02 \\
\hline 12 & Real Estat & $94,075.25$ & 50.28 & $66,880.65$ & 35.74 \\
\hline 13 & Jasa Perusahaan & $12,013.09$ & 50.28 & 4,688.91 & 19.62 \\
\hline 14 & Administrasi Pemerintahan, Pertahanan & $320,183.79$ & 50.28 & $204,055.77$ & 32.04 \\
\hline 15 & Jasa Pendidikan & $208,951.44$ & 50.28 & $35,764.97$ & 8.61 \\
\hline 16 & Jasa Kesehatan dan Kegiatan Sosial & $70,241.13$ & 50.28 & $18,347.60$ & 13.13 \\
\hline 17 & Jasa lainnya & $31,729.61$ & 50.28 & $9,761.56$ & 15.47 \\
\hline
\end{tabular}

Sumber: Hasil perhitungan dan analisis, 2019

Interpretasi hasil perhitungan seperti yang tertera pada Tabel 3 yaitu sebagai berikut:

1. Komponen Pertumbuhan Nasional.

Nilai Pertumbuhan Nasional (PN), menunjukan nilai positif untuk semua sub sektor ekonomi, ini artinya ketika pertumbuhan ekonomi di tingkat Provinsi Papua Barat adalah positif, maka akan memberikan dampak pertumbuhan yang positif juga bagi sektor-sektor ekonomi di Kota Sorong dan sektor ekonomi yang mendapat dampak terbesar dari pertumbuhan ekonomi tersebut adalah sektor konstruksi yakni sebesar Rp.730.616.340.000,- dan yang terkecil adalah sektor pengadaan listrik dan gas yaitu sebesar Rp.3.944.910.000,-

2. Komponen Pertumbuhan Proporsional.

Komponen ini sebenarnya menunjukan perbandingan antara pertumbuhan tiap sektor ekonomi dengan pertumbuhan total ditingkat Provinsi dan dampaknya terhadap pertumbuhan sektor-sektor ekonomi di bawah. Ada tiga sektor ekonomi yang bertanda negatif $(\mathrm{PPij}<0)$ atau pertumbuhannya lamban yaitu sektor pertanian, kehutanan dan perikanan, pertambangan dan penggalian, serta sektor industri pengolahan. Hal ini terjadi karena ditingkat Provinsi pertumbuhan sektor-sektor tersebut mengalami perlambanan sehingga memberikan dampak pertumbuhan yang lamban terhadap sektorsektor yang sama di Kota Sorong, dan sebaliknya empat belas sektor yang lain menunjukan pertumbuhan yang positif sehingga memberikan efek pertumbuhan yang cepat terhadap sektor-sektor yang sama di Kota Sorong (PPij > 0).

Tabel 4. Kompomen Pertumbuhan Pangsa Wilayah (PPW) dan Pergeseran Bersih (PB)

\begin{tabular}{llrrrr}
\hline \multirow{2}{*}{ No } & Lapangan Usaha & \multicolumn{2}{c}{ PPWij } & \multicolumn{2}{c}{ PBij } \\
\cline { 3 - 5 } & & \multicolumn{1}{c}{ Miliar } & \multicolumn{1}{c}{ M } & \multicolumn{1}{c}{ Miliar } & \multicolumn{1}{c}{$\%$} \\
\hline 1 & Pertanian, Kehutanan, dan Perikanan & $(98,043.43)$ & $(17.16)$ & $(100,365.32)$ & $(17.56)$ \\
\hline 2 & Pertambangan dan Penggalian & $4,873.47$ & 4.50 & $(31,398.22)$ & $(29.00)$ \\
\hline 3 & Industri Pengolahan & $(67,944.51)$ & $(14.46)$ & $(148,735.23)$ & $(31.65)$ \\
\hline 4 & Pengadaan Listrik dan Gas & $(10,432.82)$ & $(132.96)$ & $(3,026.65)$ & $(38.57)$ \\
\hline 5 & Pengadaan Air, Pengelolaan Sampah & $(6,143.14)$ & $(25.39)$ & $(6,094.28)$ & $(25.18)$ \\
\hline 6 & Konstruksi & $(100,140.24)$ & $(6.89)$ & $550,896.99$ & 37.91 \\
\hline 7 & Perdagangan Besar dan Eceran & $(494,675.29)$ & $(41.30)$ & $28,216.82$ & 2.36 \\
\hline 8 & Transportasi dan Pergudangan & $(186,131.15)$ & $(41.60)$ & $48,908.18$ & 10.93 \\
\hline 9 & Penyediaan Akomodasi Makan Minum & $(40,079.08)$ & $(40.44)$ & $(11,816.55)$ & $(11.92)$ \\
\hline 10 & Informasi dan Komunikasi & $(43,681.50)$ & $(11.19)$ & $50,928.91$ & 13.05 \\
\hline 11 & Jasa Keuangan dan Asuransi & $(75,077.84)$ & $(25.71)$ & $(51,668.00)$ & $(17.69)$ \\
\hline 12 & Real Estat & $(53,197.54)$ & $(28.43)$ & $13,683.11$ & 7.31 \\
\hline 13 & Jasa Perusahaan & $(8,994.02)$ & $(37.64)$ & $(4,305.11)$ & $(18.02)$ \\
\hline 14 & Administrasi Pemerintahan, Pertahanan & $(148,180.48)$ & $(23.27)$ & $55,875.29$ & 8.77 \\
\hline 15 & Jasa Pendidikan & $(40,309.26)$ & $(9.70)$ & $(4,544.29)$ & $(1.09)$ \\
\hline 16 & Jasa Kesehatan dan Kegiatan Sosial & $(41,670.48)$ & $(29.83)$ & $(23,322.88)$ & $(16.69)$ \\
\hline 17 & Jasa lainnya & $(14,950.26)$ & $(23.69)$ & $(5,188.70)$ & $(8.22)$ \\
\hline
\end{tabular}

Sumber: Hasil perhitungan dan analisis, 2019 


\section{Berdasarkan Tabel 4, berikut interpretasi komponen PPW dan PB}

3. Komponen Pertumbuhan Pangsa Wilayah (PPWij)

Rasio atau komponen Pertumbuhan Pangsa Wilayah menunjukkan daya saing tiap-tiap sektor ekonomi ditingkat bawah terhadap sektor ekonomi di tingkat atas. Apabila PPW $i j>0$ atau bertanda positif (+) maka sektor ekonomi tersebut memiliki daya saing yang baik terhadap daerah diatasnya, dan sebaliknya bila bertanda negatif (-) atau PPWij < 0 berarti sektor tersebut tidak memiliki daya saing terhadap daerah diatasnya. Berdasarkan hasil perhitungan tenyata hanya satu sektor saja di Kota Sorong yang memiliki daya saing terhadap sektor yang sama di Provinsi Papua Barat yaitu sektor pertambangan dan penggalian (PPW $i j>0$ ), sementara yang enam belas sektor lainnya bertanda negatif (PPWij < 0 ) artinya sektor-sektor ekonomi tersebut tidak memiliki daya saing terhadap sektor-sektor yang sama di Provinsi Papua Barat.

4. Pergeseran Bersih (PBij)

Komponen ini bertujuan untuk mendapatkan sektor dengan pertumbuhan yang progresif, artinya benar-benar memiliki pertumbuhan yang positif $(+)$ yang didapat dari penjumlahan komponen PP $i j$ dengan PPW $i j$. Dari hasil perhitungan ada 6 sektor ekonomi yang bertanda positif (+) atau PB $i j>0$ yaitu sektor konstruksi, sektor perdagangan besar dan eceran, sektor transportasi dan pergudangan, sektor informasi dan komunikasi, sektor real estate, dan sektor administrasi pemerintahan pertahanan dan jaminan sosial. Sektor-sektor ekonomi ini memiliki pertumbuhan yang progresif (positif). sebaliknya ada 11 sektor ekonomi yang memiliki tanda negatif (-) PBij < 0 artinya sektor-sektor ekonomi tersebut memiliki pertumbuhan yang lamban.

5. Mengevaluasi Pertumbuhan Sektor Perekonomian.

Profil pertumbuhan sektor digunakan untuk mengevaluasi pertumbuhan sektor ekonomi di Kota Sorong pada kurun waktu 2013 sampai 2018. Profil perekonomian ini ditentukan dengan perhitungan persen perubahan PP $i j$ dan persen perubahan PPW $i j$, seperti ditunjukan pada Tabel 4 berikut:

Tabel 5. Persen Perubahan PPij dan Persen Perubahan PPWij

\begin{tabular}{|c|c|c|c|}
\hline & Lapangan Usaha & PPij (\%) & PPWij (\%) \\
\hline A & Pertanian & $-0,406$ & $-17,158$ \\
\hline B & Pertambangan & $-33,496$ & 4,500 \\
\hline $\mathrm{C}$ & Industri Pengolahan & $-17,194$ & $-14,460$ \\
\hline D & Listrik dan Gas & 94,389 & $-132,962$ \\
\hline E & Pengadaan Air,Sampah & 0,202 & $-25,386$ \\
\hline $\mathrm{F}$ & Konstruksi & 44,800 & $-6,891$ \\
\hline $\mathrm{G}$ & Perdagangan Besar dan Eceran & 43,660 & $-41,304$ \\
\hline $\mathrm{H}$ & Transportasi dan Pergudangan & 52,533 & $-41,602$ \\
\hline I & Penyediaan Akomodasi & 28,518 & $-40,442$ \\
\hline $\mathrm{J}$ & Informasi dan Komunikasi & 24,235 & $-11,189$ \\
\hline $\mathrm{K}$ & Jasa Keuangan dan Asuransi & 8,015 & $-25,706$ \\
\hline $\mathrm{L}$ & Real Estat & 35,743 & $-28,430$ \\
\hline $\mathrm{M}$ & Jasa Perusahaan & 19,624 & $-37,641$ \\
\hline $\mathrm{N}$ & Administrasi Pemerintahan & 32,042 & $-23,268$ \\
\hline $\mathrm{O}$ & Jasa Pendidikan & 8,605 & $-9,699$ \\
\hline $\mathrm{P}$ & Jasa Kesehatan & 13,133 & $-29,826$ \\
\hline $\mathrm{Q}$ & Jasa lainnya & 15,467 & $-23,689$ \\
\hline
\end{tabular}

Sumber: Hasil perhitungan dan analisis, 2019 


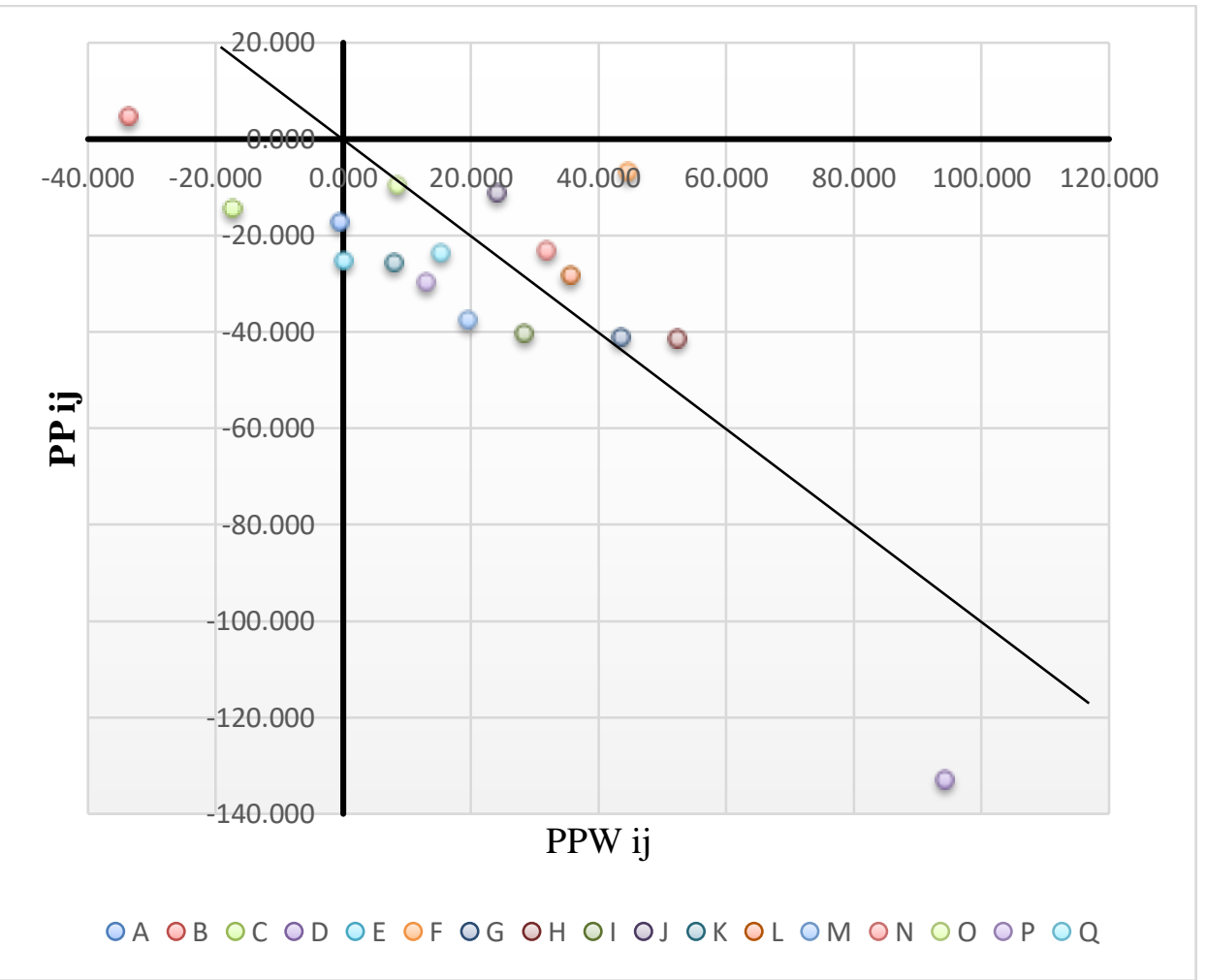

Gambar 3. Profil Pertumbuhan Sektor Ekonomi Kota Sorong Sumber: Hasil perhitungan dan analisis, 2019

Berdasarkan Gambar 3 di atas, penjelasan masing-masing kuadran yang terdapat pada Gambar 4 adalah sebagai berikut:

a. Kuadran I merupakan kuadran dimana PP dan PPW sama-sama bernilai positif. Hal ini menunjukkan bahwa sektor-sektor ekonomi di Kota Sorong memiliki pertumbuhan yang cepat (dilihat dari nilai PPnya) dan memiliki daya saing yang lebih baik apabila dibandingkan dengan Provinsi Papua Barat (dilihat dari nilai PPW-nya). Perekonomian Kota Sorong tidak ada sektor ekonomi yang berada pada kuadran I.

b. Kuadran II menunjukkan bahwa sektor-sektor ekonomi di Kota Sorong pertumbuhannya cepat (PP-nya bernilai positif), tetapi daya saing wilayah untuk sektor-sektor tersebut dibandingkan dengan di tingkat Provinsi Papua Barat kurang baik (PPW-nya bernilai negatif), pada kuadran ini hanya terdapat ekonomi yaitu sektor pertambangan.

c. Kuadran III merupakan kuadran dimana PP dan PPW bernilai negatif. Hal ini menunjukkan bahwa sektorsektor ekonomi di Kota Sorong yang bersangkutan memiliki pertumbuhan yang lambat dengan daya saing yang kurang baik jika dibandingkan dengan tingkat Provinsi Papua Barat. Sektor ekonomi yang berada pada kuadran ini adalah sektor pertanian, industri pengolahan, dan pengadaan air pengelolan sampah.

d. Kuadran IV menunjukkan bahwa sektor-sektor ekonomi di Kota Sorong memiliki pertumbuhan lamban (dilihat dari nilai PP-nya yang negatif), tetapi daya saing wilayah untuk sektor-sektor tersebut baik jika dibandingkan dengan tingkat Provinsi Papua Barat (dilihat dari nilai PPW-nya yang positif). Sektor ekonomi yang berada pada kuadran ini adalah sektor listrik, konstruksi, perdagangan besar dan eceran, transportasi dan pergudangan, penyediaan akomodasi, informasi dan komunikasi, jasa keuangan dan asuransi, real estate, jasa perusahaan, administrasi pemerintahan, jasa pendidikan, jasa kesehatan, dan sektor jasa lainnya.

e. Selanjutnya sektor dengan pertumbuhan progresif atau yang berada di atas daerah garis diagonal $45^{\circ}$ terdiri dari sektor-sektor konstruksi, sektor perdagangan besar dan eceran, sektor transportasi dan pergudangan, sektor informasi dan komunikasi, sektor real estate, dan sektor administrasi pemerintahan pertahanan dan jaminan sosial. Sektor-sektor yang berada di bawah garis digonal $45^{\circ}$ adalah sektor yang tidak progresif terdiri dari sektor Pertanian, sektor Pertambangan dan Penggalian, sektor Industri Pengolahan, sektor Pengadaan Listrik dan Gas, sektor Pengadaan Air dan Pengolahan Sampah, sektor Penyediaan akomodasi, sektor Jasa Keuangan dan Asuransi, sektor Jasa Perusahaan, sektor Jasa Pendidikan, sektor Jasa Kesehatan dan Kegiatan Sosial, serta sektor Jasa Lainnya.

\section{KESIMPULAN}

Simpulan dari penelitian ini yaitu sebagai berikut: 
1. Pertumbuhan positif pada perekonomian Provinsi Papua Barat telah memberikan dampak positif bagi sektor-sektor ekonomi di Kota Sorong, dan sektor yang mendapat dampak terbesar dari pertumbuhan ekonomi Provinsi Papua Barat adalah adalah sektor konstruksi dan yang terkecil adalah sektor pengadaan listrik dan gas.

2. Secara sektoral pun pertumbuhannya dipengaruhi oleh pertumbuhan sektor yang sama di Papua Barat, dimana pertumbuhan negatif sektor pertanian, kehutanan dan perikanan, pertambangan dan penggalian, serta sektor industri pengolahan di tingkat provinsi menyebabkan lambannya pertumbuhan sektor-sektor yang sama di Kota Sorong.

3. Dari sisi daya saing ternyata hanya satu sektor ekonomi di Kota Sorong yang memiliki daya saing terhadap sektor ekonomi yang sama di tingkat provinsi, yaitu sektor pertambangan dan penggalian.

4. Sektor-sektor ekonomi dengan pertumbuhan yang progresif hanya enam sektor dan sebanyak sebelas sektor ekonomi yang memiliki pertumbuhan yang lamban.

\section{DAFTAR PUSTAKA}

[1] M. Witjaksono, "Pembangunan Ekonomi dan Ekonomi Pembangunan: Telaah Istilah dan Orientasi dalam Konteks Studi Pembangunan,” J. Ekon. Stud. Pembang. Univ. Malang, vol. 1, no. 1, pp. 1-12, 2009, [Online]. Available: http://journal.um.ac.id/index.php/jesp/article/view/5120/1847.

[2] S. Syamsurijal, "Pengaruh Tingkat Kesehatan Dan Pendidikan Terhadap Tingkat Pertumbuhan Pendapatan Perkapita Di Sumatera Selatan,” J. Econ. Dev. Policy, vol. 6, no. 1, pp. 1-9, 2008, doi: 10.29259/jep.v6i1.4841.

[3] E. D. Ratnasari, "Sectors Analysis and Determination of GDP Forming Leading Sector In District Kebumen," J. Fokus Bisnis, vol. 13, no. 01, pp. 1-29, 2014, [Online]. Available: http://journal.uinalauddin.ac.id/index.php/Iqtisaduna/article/download/1155/1121.

[4] M. Diana, D. Sulistiowati, and S. Hadi, “Analisis Sektor Ekonomi Unggulan Di Provinsi Maluku Utara," J. Ilmu Eknomi, vol. 1, no. 4, pp. 400-415, 2017, [Online]. Available: http://ejournal.umm.ac.id/index.php/jie/article/view/6280.

[5] J. F. Fau, "Analisis Potensi Sektoral Ekonomi Kabupaten Nias Selatan Metode Anaisis Shift-Share dan Location Quotient," J. Educ. Dev., vol. 5, no. 1, pp. 26-30, 2018, doi: https://doi.org/10.37081/ed.v5i1.368.

[6] M. Basuki et al., "Analisis potensi sektor potensi pertanian di Kabupaten Kediri Tahun 2010-2014," J. Ekon. Pembang., vol. 14, no. 1, pp. 99-111, 2016, doi: 10.1017/CBO9781107415324.004.

[7] I. Safwadi and M. S. Rangkuti, "Analisis Struktur Ekonomi dan Sektor Unggulan Kabupaten Aceh Besar," $J$. Hum. J. Ilmu Sos. Ekon. dan Huk., vol. 2, no. 1, pp. 39-48, 2018, doi: https://doi.org/10.30601/humaniora.v2i1.52.

[8] J. Tipka, "Analisis LQ Dan Analisis Shift-Share Dalam Pemanfaatan Ekonomi Sektor Kabupaten Maluku Tengah Tahun 2008-2010," J. Barekeng, vol. 8, no. 1, pp. 17-24, 2014, [Online]. Available: https://ojs3.unpatti.ac.id/index.php/barekeng/article/view/259/210.

[9] I. Masloman, "Analisis Pertumbuhan Ekonomi Serta Sektor Yang Potensial Dan Bardaya Saing Di Kabupaten Minahasa Selatan,” J. Berk. Ilm. Efisiensi, vol. 18, no. 01, pp. 46-56, 2018, [Online]. Available: https://ejournal.unsrat.ac.id/index.php/jbie/article/view/19820.

[10] M. Hidayat and R. Darwin, "Analisis Sektor Unggulan Dalam Pengembangan Wilayah Kabupaten Kepulauan Meranti," Media Trend, vol. 12, no. 2, pp. 156-167, 2017, doi: 10.21107/mediatrend.v12i2.3081.

[11] H. Suaidy, “Analisis Pertumbuhan Ekonomi Wilayah Kota Sorong Tahun 2013-2016,” J. Noken Ilmu-Ilmu Sos., vol. 2, no. 2, pp. 81-89, 2017, doi: https://doi.org/10.33506/jn.v2i2.34.

[12] BPS Kota Sorong, "PDRB Kota Sorong Atas Dasar Harga Konstan Menurut Lapangan Usaha, 2010 - 2019," 2019. https://sorongKota.bps.go.id/dynamictable/2017/04/13/101/pdrb-Kota-sorong-atas-dasar-harga-konstanmenurut-lapangan-usaha-2010---2016.html.

[13] D. Pratiwi and H. Warnaningtyas, "Analisis Strategi Pembangunan Wilayah Kabupaten Madiun Melalui Sektor Unggulan," J. Ekomaks, vol. 4, no. 2, pp. 1-14, 2015, [Online]. Available: http://unmermadiun.ac.id/ejurnal/index.php/ekomaks/article/view/60.

[14] H. Hajeri, E. Yurisinthae, and E. Dolorosa, "Analisis Penentuan Sektor Unggulan Perekonomian di Kabupaten Kubu Raya," J. Ekon. Bisnis dan Kewirausahaan, vol. 4, no. 2, p. 253, 2015, doi: 10.26418/jebik.v4i2.12485.

[15] E. J. Mangilaleng, D. Rotinsulu, and W. Rompas, “Analisis Sektor Unggulan Kabupaten Minahasa Selatan," J. Berk. Ilm. Efisiensi, vol. 15, no. 04, pp. 193-205, 2015, [Online]. Available: https://ejournal.unsrat.ac.id/index.php/jbie/article/view/9482/9057.

[16] N. Syamsiyah and G. Kurnia, "Analisis Struktur Perekonomian Berdasarkan Pendekatan Shift - Share Dalam Pengembangan Agrowisata Di Kabupaten Cirebon," J. Agribisnis Terpadu, vol. 10, no. 2, pp. 201-2011, 2017, doi: 10.33512/jat.v10i2.5072.

[17] H. Hamzah, Ekonomi Pembangunan dan Perencanaan. Makasar: Kretakupa Print, 2009.

[18] H. Suaidy, “Analisis Pertumbuhan Ekonomi Wilayah Sorong 2013-2016,” Noken, vol. 2, no. 2, pp. 81-89, 2017, doi: https://doi.org/10.33506/jn.v2i2.34. 
[19] BPS Papua Barat, "Produk Domestik Regional Bruto Menurut Lapangan Usaha 2014-2018," Manokwari: Badan Pusat Statistik Provinsi Papua Barat, 2019.

[20] BPS Papua Barat, "Produk Domestik Regional Bruto Provinsi Papua Barat Menurut Lapangan Usaha $2013-$ 2017,’ Manokwari: Badan Pusat Statistik Provinsi Papua Barat, 2018. 